\title{
Working
}

Paper 


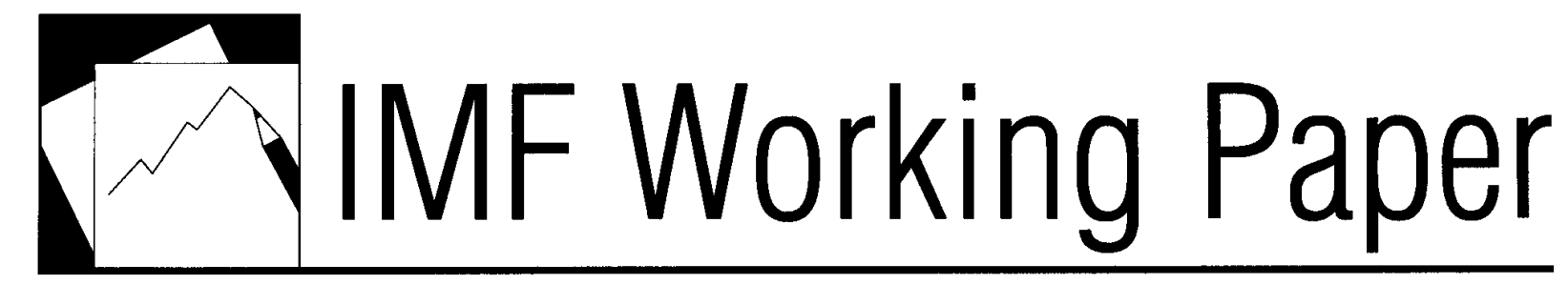

Capital Inflows, Financial Development, and Domestic Investment:

Determinants and Inter-Relationships

Oana Luca and Nikola Spatafora 


\title{
IMF Working Paper
}

Research Department

\section{Capital Inflows, Financial Development, and Domestic Investment: Determinants and Inter-Relationships}

\author{
Prepared by Oana Luca and Nikola Spatafora ${ }^{1}$
}

Authorized for distribution by Andrew Berg

0 D 2012

\section{This Working Paper should not be reported as representing the views of the IMF.}

The views expressed in this Working Paper are those of the author(s) and do not necessarily represent those of the IMF or IMF policy. Working Papers describe research in progress by the author(s) and are published to elicit comments and to further debate.

\begin{abstract}
We examine determinants of, and interactions between, capital inflows, financial development, and domestic investment in developing countries during 2001-07, a period of surging global liquidity and low interest rates. Reductions in the global price of risk and in domestic borrowing costs were the main contributors to the increase over time in net capital inflows and domestic credit. However, the large cross-country differences in domestic and international finance are best explained by fundamentals such as institutional quality, access to international export markets, and an appropriate macroeconomic policy. Both private capital inflows and domestic credit exert a positive effect on investment; they also mediate most of the investment impact of the global price of risk and domestic borrowing costs. Surprisingly, neither greater domestic credit nor greater institutional quality increase the extent to which capital inflows translate into domestic investment.
\end{abstract}

JEL Classification Numbers: F21, F32

Keywords: Capital flows, Financial Development, Investment, Developing Countries Authors’ E-Mail Addresses: oluca@,imf.org,nspatafora@,imf.org.

\footnotetext{
${ }^{1}$ We gratefully acknowledge comments by Andrew Berg, Andrew Burns, Hans Timmer, and seminar participants at the IMF and World Bank.
} 
Abstract

I. Introduction $\underline{3}$

II. Model specifications

A. Determinants of Capital Inflows and Domestic Credit ...........................................

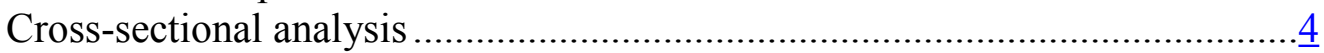

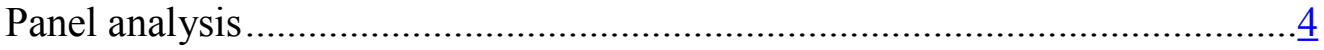

B. Determinants of Investment ……………………........................................

Cross-sectional analysis .....................................................................

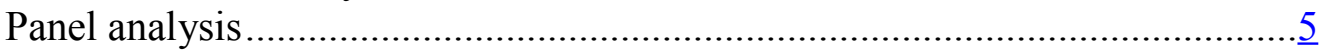

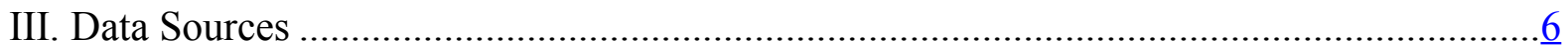

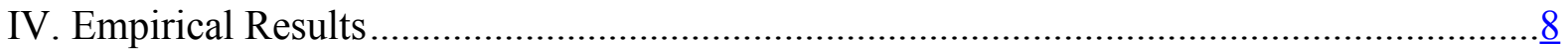

A. Determinants of Capital Inflows and Domestic Credit ............................................ $\frac{8}{8}$

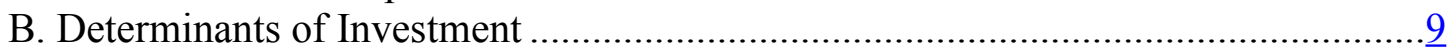

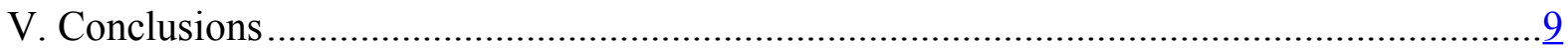

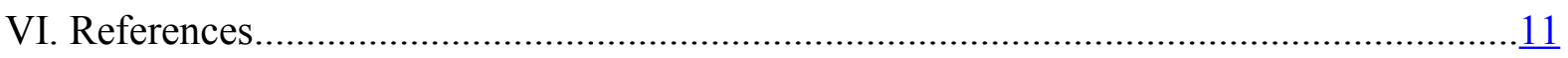

Tables

Table 1. Private Finance: Cross-Country Regressions ………………………………....13

Table 2. Private Finance: Panel Regressions ...............................................................14

Table 3. Decomposition of Cross-Country Differences in Financial Variables .......................15

Table 4. Decomposition of Inter-Temporal Changes in Financial Variables ...........................15

Table 5. Investment: Cross-Country Regressions .............................................................

Table 6. Investment: Panel Regressions (Fixed Effects, Difference GMM, and System GMM)

Figures

Figure 1. Covariates of Private Finance in Developing Countries

Appendix Tables

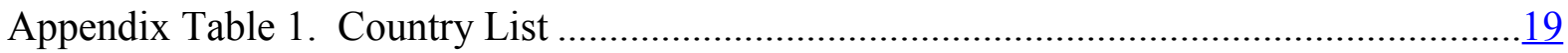

Appendix Table 2. Description of Variables and Data Sources …………………………... 20

Appendix Table 3. Descriptive Statistics........................................................................... 


\section{INTRODUCTION}

Between 2001 and the collapse of Lehman Brothers in the fall of 2008, international markets saw a global credit boom, characterized by an unprecedented loosening of global monetary conditions, a decline in global interest rates, ${ }^{2}$ and a general reduction in the price of risk. As a result, throughout the developing world financial conditions relaxed, and interest rates and spreads declined. This decline in borrowing costs coincided with a rapid increase in financial inflows, domestic credit, and capital-market valuations in most developing regions.

Based on these observations, we address two key research questions. First, what factors explain whether, in response to the global loosening of monetary conditions, domestic and international finance in developing countries also expanded? Second, what factors explain whether the surge in global liquidity and in financial intermediation translated into productive investment in any given developing country? Our contribution is twofold. First, we focus on a very specific period, characterized by large, exogenous financial shocks, which suggests that it may be possible to estimate with some confidence any underlying causal relationships. Second, our analysis employs a new measure of the global price of risk.

This paper is related to three main strands of the literature. First, studies of determinants of capital inflows, which in particular distinguish between global (or "push") factors and domestic (or "pull") factors, often finding important roles for both. ${ }^{3}$ Second, analyses of the effect on growth and economic development of the surge in capital inflows to developing countries over the past decades. ${ }^{4}$ Third, the voluminous literature on the relationship between financial development and economic growth. ${ }^{5}$ Such studies typically find that capital inflows, financial development, and the size and efficiency of financial institutions are all positively correlated with productive efficiency and growth in the cross-sectional data. However, the literature is not unanimous in identifying a causal relationship, particularly between capital inflows and growth.

The rest of this paper is set out as follows. Section II discusses our empirical strategy. Section III describes the data. Section IV presents the findings. Section V concludes.

\footnotetext{
${ }^{2}$ Long-term real interest rates were about 1.5-2 percent during this period, compared with 3.5 percent during the U.S. expansion in the second half of the 1990s (World Bank, 2010).

${ }^{3}$ For instance, Fratzscher (2011) finds that global factors were relatively more important as a driver of net capital flows during both 2005-07 and the 2007-08 financial crisis, but domestic factors have dominated in the recovery period since. Again, Bacchetta and van Wincoop (2012) and Gourio et al. (2010) find strong evidence that global shocks are transmitted to financial markets and capital flows.

${ }^{4}$ See Dell'Ariccia et al. (2008), and Mody and Murshid (2005).

${ }^{5}$ See Baltagi et al (2008), Shan (2005), Aghion et al. (2004), Nourzad (2002), Al-Yousif (2002), Al-Taimimi et al. (2001), Levine et al. (2000), Demetriades and Hussein (1999), Levine and Zervos (1998), Rousseau and Wachtel (1998), and Levine (1997).
} 


\section{MODEL SPECIFICATIONS}

We address the above questions using both cross-sectional and panel estimation methods. The former allow us to analyze country-specific determinants of capital inflows, domestic credit, and investment. The latter also enable us to investigate the effects of countryinvariant factors, such as changes in global risk conditions.

\section{A. Determinants of Capital Inflows and Domestic Credit}

\section{Cross-sectional analysis}

To estimate the effect of country-specific factors on domestic and external finance, we start with a pure cross-sectional setting, using a sample of 103 countries. The basic estimation equation is

$$
Y_{i}=\alpha_{0}+\alpha_{1}^{\prime} X_{i}+\alpha_{2}{ }^{\prime} N R_{i}+\varepsilon_{i},
$$

where the subscript $i$ denotes the country. $\mathrm{Y}_{\mathrm{i}}$ represents, in turn, the ratio to GDP of: (1) international net capital inflows; and (2) domestic credit, defined as the total credit to the private sector. The vector $\mathrm{X}_{\mathrm{i}}$ includes a range of variables drawn from the existing literature:

- The domestic cost of capital.

- Institutional quality.

- Exports of goods and non-factor services, as indicators of general economic openness.

- The government budget balance and CPI inflation, as indicator of the appropriateness of macroeconomic policy.

- Net capital inflows (in the equation for domestic credit). We allow capital inflows to affect domestic credit growth. In contrast, we assume that domestic credit does not directly affect capital inflows, although both may be affected by other variables.

We also control for the effect of natural-resource endowments by including indicators of natural resource intensity, $\mathrm{NR}_{\mathrm{i}}$. All dependent variables are constructed using average values during 2001-07. In the baseline specification, the independent variables are also constructed using average values over the same period. Alternative specifications aim to minimize endogeneity issues by employing either initial values, or lagged values (specifically, the average values during 1998-2000).

\section{Panel analysis}

Both as a robustness check, and to explore the role of the country-invariant global risk premium, a second set of estimations is run using panel regressions on annual data. The basic panel estimation equation is 


$$
Y_{i t}=\mu_{i}+\beta_{1}^{\prime} X_{i t}+\beta_{2} Z_{t}+\zeta_{i t}
$$

where the subscripts $i$ and $t$ denote, respectively, the country and the year. As in the crosssectional analysis, $Y_{i t}$ represents, in turn, the ratio to GDP of: (1) international net capital inflows (we consider separately total private flows, debt flows - aggregated and broken down by bond flows and bank loans, and equity flows); and (2) domestic credit. $X_{i t}$ is defined as in the cross-sectional analysis. $Z_{t}$ is the country-invariant global risk premium. The countryspecific fixed effects, $\mu_{i}$, control for time-invariant factors that affect $Y_{i t}$, such as country size. For the independent variables, one-year-lagged values are employed.

\section{B. Determinants of Investment}

\section{Cross-sectional analysis}

In order to examine the determinants of individual countries' macroeconomic performance, a modified form of equation (1) is estimated, with the ratio of investment to GDP as the dependent variable:

$$
I_{i}=\alpha_{0}+\alpha_{1}^{\prime} X X_{i}+\alpha_{2}^{\prime} N R_{i}+\varepsilon_{i}
$$

The list of independent variables includes, as before, the cost of capital and indicators of natural resource intensity. ${ }^{6}$ In addition, the vector XX includes indicators of institutional quality, and measures of both capital inflows and domestic credit. Interactions between capital inflows and institutional quality, as well as between capital inflows and domestic credit, are added to capture the potential impact of domestic conditions on the efficiency with which capital inflows are invested. We also control for growth in the terms of trade (weighted by the trade ratio), and in export markets (weighted by the export ratio). Alternative specifications include lagged investment as an additional regressor, to better capture the dynamics.

\section{Panel analysis}

Again, both as a robustness check, and to explore the role of the country-invariant risk premium, a second set of investment estimations is run using panel regressions on annual data. The basic panel estimation equation is

$$
I_{i t}=\mu_{i}+\beta_{1}^{\prime} X X_{i t}+\beta_{2} Z_{t}+\zeta_{i t}
$$

We also present alternative specifications which include lagged investment as a regressor. These equations are estimated using the Blundell and Bond (1998) GMM dynamic panel

\footnotetext{
${ }^{6}$ Previous studies have found that natural resources play an important role in explaining long-run differences in private investment in developing countries (Bond and Malik, 2009).
} 
estimator. The latter technique helps correct biases arising from endogeneity (the causality between investment and capital inflows or domestic credit can run in both directions) and from the use of the lagged dependent variable. The Arellano-Bond estimator is also appropriate because the panel dataset has a short time dimension $(\mathrm{T}=7)$ and a large country dimension $(\mathrm{N}=110)$.

\section{Data Sources}

The global risk premium, or international price of risk, is proxied by the Kennedy and Palerm (2009) measure of the synthetic risk premium in high-income countries. This measure, which is relatively new to the literature, is based on factor analysis. Specifically, Kennedy and Palerm consider a sample of: (i) spreads on corporate bonds for the United States and the euro area; (ii) the implied risk premium on equities for each economy; and (iii) a representative global EMBI+ spread. The global risk premium is then calculated as the first principal component.

The cost of capital is measured as the sum of the required return on investment and an assumed rate of capital depreciation of 7 percent. $^{7}$ The required return on investment is measured as the sum of the global risk-free rate (the U.S. T-bill rate), plus a country-specific credit spread. Credit spreads were measured using the market spread on the country's sovereign bonds (from the J.P. Morgan EMBI Global stripped spread) for those countries with data available; for the remaining countries, regional averages were used instead.

All the capital flow variables are constructed using data from the World Bank's Global Development Finance (GDF) database. This source provides a more comprehensive coverage of the different types of component sub-flows and has fewer gaps than comparable sources. ${ }^{8}$ Its main limitation is that it covers exclusively developing countries, and therefore does not allow for comparisons with advanced economies (that said, the determinants of capital flows to developed countries are likely to be very different). Private net capital flows consist of net equity inflows (FDI flows and portfolio equity) and net debt inflows (bond issuance, bank lending, short-term debt, and net lending from other private creditors). Together with net official inflows (public and publicly guaranteed debt from official creditors, plus IMF purchases minus IMF repurchases), they represent total capital inflows to the recipient country. The net debt flows (either net lending or net disbursements) are disbursements minus principal repayments.

The quality of the institutional environment is proxied by the average of the six governance indicators in the Kaufmann-Kraay-Mastruzzi (2009; henceforth KKM) database. The six

\footnotetext{
${ }^{7}$ See World Bank (2010), ch. 2, p. 25, for a discussion of appropriate assumptions regarding depreciation rates.

${ }^{8}$ For a comparison of the different data sources available for international capital flows, see Dorsey et al. (2008), discussion and Annex Table 1.
} 
governance indicators are: voice and accountability; political stability and absence of violence/terrorism; government effectiveness; regulatory quality; rule of law; and control of corruption. On each governance indicator, countries are ranked on a scale from 1 to 100. Percentile rank indicates the percentage of countries worldwide that rate below the selected country, with higher values indicating better governance ratings. An alternative proxy for the institutional environment, the ICRG law and order ranking, was used to check robustness of the results. ${ }^{9}$

The terms-of-trade index, weighted by the trade ratio, captures the impact of a proportionate change in the terms of trade, given the economy's level of openness. We adopt two measures of real-side openness: (i) exports of goods and non-factor services as a share of GDP; and (ii) export market growth, calculated as the weighted growth rate of total imports in a country's trade partners, where the weights equal that trade partner's average share in the country's total exports over 2000-03. All these measures are derived from the IMF's International Financial Statistics (IFS) and World Economic Outlook databases, and the World Bank's Global Economic Prospects database.

The remaining data are derived from World Bank's World Development Indicators (WDI) and the IFS databases. The series include indicators of macroeconomic stability (the fiscal balance as a share of GDP, and the consumer price index) and domestic credit (domestic credit to the private sector as a share of GDP). Additional data on exports of fuel and metals were extracted from WDI to build indicators of natural-resource intensity: countries in the upper quartile of the (fuel exports / GDP) and/or the (metals exports / GDP) distribution are defined as resource-rich.

The sample contains 103 countries, listed in Appendix Table 1. Appendix Table 2 summarizes the data sources for the key variables, and Appendix Table 3 presents summary statistics for each variable. In addition, Figure 1 presents the simple bivariate correlations between, on the one hand, domestic credit and foreign private capital inflows, and on the other hand several potential determinants of private finance (including the cost of capital, institutional quality, and exports intensity). Private finance (represented by foreign capital inflows and domestic credit) is correlated negatively with borrowing costs, and positively with institutional quality and real-side openness. To draw robust policy conclusions, we next turn to multivariate analysis.

\footnotetext{
${ }^{9}$ The KKM index is preferred because it has wider country coverage than the ICRG indicator.
} 


\section{EMPIRICAL RESUlts}

\section{A. Determinants of Capital Inflows and Domestic Credit}

We present the results using both net capital inflows and domestic credit as the dependent variables. For each of the two, we report results for different specifications with the explanatory variables calculated in turn as:

1. Contemporaneous values, in the form of averages over 2001-07;

2. Initial values, given by the first available year between 2001 and 2007; and

3. Lagged values, in the form of averages over 1998-2000.

As a variation on (3) above, we also use lagged values as instrumental variables. The crosscountry regressions consistently suggest that capital inflows into the average developing country are significantly affected by institutional quality, the share of exports in GDP, and the average rate of export growth over the previous decade (Table 1, columns 1-4). A 10percentage-point increase in exports / GDP leads on average to a 1.1 percentage point of GDP increase in net capital inflows. Controlling for the export share, countries with higher export growth rates between 1990 and 1997 attracted less capital inflows between 2001 and 2007.

The level of domestic credit is significantly affected by the cost of capital, institutional quality, and exports (Table 1, columns 5-8). Borrowing costs have a particularly large, negative effect on domestic credit. For the average developing country, a 100 basis point decline in borrowing costs (relative to the pre-2001 average) results in an increase in domestic credit of 0.8 percentage points of GDP (using the preferred specification in column 8). There is also some evidence that domestic credit is negatively affected by inflation, as well as by budget deficits (consistent with crowding out).

Panel regressions allow us to explore the role of the country-invariant global risk premium. The results confirm statistically significant associations between net capital inflows and the global price of risk (Table 2). There is also a significant association between domestic credit on the one hand, and net private capital inflows, the global price of risk, and institutional quality on the other.

Quantitatively, the panel estimates indicate that a 1 point decline in the measure of the global price of risk, equivalent to the decline observed between 2003 and 2007, results in a 1.8 percentage point of GDP increase in foreign capital inflows, and a 1.7 percentage point of GDP increase in domestic credit. Controlling for the global price of risk, the cost of capital does not have an independent influence on either capital inflows or domestic credit.

Disaggregating total capital inflows into their equity and debt components, and running separate panel regressions for each, suggests that equity flows are relatively more sensitive to 
changes in the global price of risk than debt flows. Institutional quality also has a significant effect on equity inflows.

Overall, cross-country differences in the level of financial intermediation are very large and are best explained by fundamental factors such as the quality of institutions, access to international export markets, cost of capital, and inflation (Table 3). In contrast, lower global risk and the overall expansion of global liquidity are the biggest contributors to the increase over time in the extent of intermediation in developing countries (Table 4).

\section{B. Determinants of Investment}

In the second part of the analysis, we examine the effect that the liquidity boom had on developing-country investment during 2001-07. Cross-country regressions indicate a negative and significant impact of borrowing costs on investment (Table 5, specifications 1 , 2, and 4). Likewise, private net capital inflows have a positive and significant impact on investment. Controlling for lagged investment, the results remain similar. The results also indicate strong persistence in investment. Neither institutional quality nor domestic credit affect the extent to which capital inflows translate into domestic investment in the preferred IV specification.

The panel fixed-effects regressions indicate that institutional quality, domestic credit, and export markets exert a positive effect on investment (Table 6, column 1). In addition, growth in the (trade-weighted) terms of trade is associated with higher investment. Again, neither institutional quality nor domestic credit affect the extent to which capital inflows translate into domestic investment. Dynamic panel specifications yield slightly different results (columns 2-5). In the first-difference GMM specification, domestic credit has a positive effect on investment. In the system GMM, it is instead net capital inflows that affect investment; the fiscal balance also exerts a statistically significant effect. After controlling for these variables, neither the global price of risk, nor domestic borrowing costs, exert any additional direct effect on investment. Put differently, and in light of the previous results, both the global price of risk and domestic borrowing costs affect investment mainly through their impact on net capital inflows and domestic credit.

\section{Conclusions}

This paper explores empirically some determinants of, and interactions between, capital inflows, domestic credit, and domestic investment in developing countries between 2001 and 2007. This period saw an unprecedented loosening of global monetary conditions, resulting in a rapid decline in interest rates and spreads in most developing regions. It also coincided with a rapid increase in financial inflows, domestic credit, and capital-market valuations throughout the developing world. The presence of large, exogenous financial shocks suggests that it may be possible to estimate with some confidence any underlying causal relationships. 
Cross-sectional and panel techniques find that reductions in the global price of risk and in domestic borrowing costs were the main contributors to the increase over time in net capital inflows and domestic credit. That said, cross-country differences in international and domestic finance are very large, and are best explained by fundamental factors such as institutional quality, access to international export markets, and an appropriate macroeconomic policy.

Further, both net capital inflows and domestic credit exert a positive effect on investment. Any effect of the global price of risk and domestic borrowing costs arises mainly through their impact on net capital inflows and domestic credit. Surprisingly, neither greater institutional quality nor greater domestic credit increase the extent to which capital inflows translate into domestic investment. Future research should investigate further the relationship between surges in global liquidity and productive investment in developing countries. 


\section{REFERENCES}

Aghion, Philippe, Peter Howitt, and David Mayer-Foulkes, 2004, "The Effect of Financial Development on Convergence: Theory and Evidence," NBER Working Paper 10358.

Al-Taimimi, Hussein A. Hassan, Mouawiya Al-Awad, and Husni Charif, 2001, "Finance and Growth: Evidence from Some Arab Countries," www.fmpm.ch/docs/5th/Al_Tamini.pdf.

Al-Yousif, Khalifa Yousif, 2002, "Financial Development and Economic Growth: Another Look at the Evidence from Developing Countries," Review of Financial Economics 11(2): 131-50.

Arestis, Philip, and Panicos Demetriades, 1997, "Financial Development and Economic Growth: Assessing the Evidence," Economic Journal 107(442): 783-799.

Bacchetta, Philippe, and Eric van Wincoop, 2012, "Sudden Spikes in Global Risk," mimeo.

Baltagi, Badi, Panicos Demetriades, and Siong Hook Law, 2008, "Financial Development and Openness: Evidence from Panel Data," Center for Policy Research Working Paper 107.

Blundell, Richard, and Stephen Bond, 1998, "Initial Conditions and Moment Restrictions in Dynamic Panel Data Models," Journal of Econometrics 87: 115-43.

Bond, Stephen, and Adeel Malik, 2009, "Natural resources, Export Structure, and Investment," Oxford Economic Papers 61(4): 675-702.

Dell'Ariccia, Giovanni, Julian di Giovanni, André Faria, M. Ayhan Kose, Paolo Mauro, Jonathan D. Ostry, Martin Schindler, and Marco Terrones, 2008, "Reaping the Benefits of Financial Globalization," IMF Occasional Paper 264 (Washington: International Monetary Fund).

Demetriades, Panicos O., and Khaled A. Hussein, 1999, "Does Financial Development Cause Economic Growth? Time Series Evidence from 16 Countries," Journal of Development Economics 51(2): 387-411.

Dorsey, Thomas, Helaway Tadesse, Sukhwinder Singh, and Zuzana Brixiova, 2008, “The Landscape of Capital Flows to Low-Income Countries,” IMF Working Paper 08/51

Fratzscher, Marcel, 2011, "Capital Flows, Push versus Pull Factors and the Global Financial Crisis,” NBER Working Paper No. 17357.

Gourio, François, Michael Siemer, and Adrien Verdelhan, 2011, "International Risk Cycles," NBER Working Paper No. 17277. 
Kaufmann, Daniel, Aart Kraay, and Massimo Mastruzzi, 2009, “Governance Matters VIII: Aggregate and Individual Governance Indicators, 1996-2008,” World Bank Policy Research Working Paper 4978.

Kennedy, Mike, and Angel Palerm, 2009, "Emerging market bond spreads: The role of world financial-market conditions and country specific factors," Prospects Paper, Development Prospects Group, World Bank.

Levine, Ross, 1997, "Financial Development and Economic Growth: Views and Agenda," Journal of Economic Literature 35(2): 688-726.

Levine, Ross, Norman Loayza, and Thorsten Beck, 2000, "Financial Intermediation and Growth: Causality and Causes," Journal of Monetary Economics 46: 31-77.

Levine, Ross, and Sara Zervos, 1998, "Stock Markets, Banks, and Economic Growth," American Economic Review 88(3): 537-58.

Mody, Ashoka, and Antu Panini Murshid, 2005, "Growing Up with Capital Flows," Journal of International Economics 65: 249-266.

Nourzad, Farrokh, 2002, "Financial Development and Productive Efficiency: A Panel Study of Developed and Developing Countries," Journal of Economics and Finance 26(2): 138-49.

Rousseau, Peter L., and Paul Wachtel, 1998, "Financial Intermediation and Economic Performance: Historical Evidence from Five Industrial Countries," Journal of Money, Credit, and Banking 30: 657-78.

Shan, Jordan, 2005, “Does Financial Development 'Lead' Economic Growth? A Vector Autoregression Appraisal," Applied Economics 37: 1353-67.

World Bank, 2011, Global Development Finance (Washington: World Bank).

World Bank, 2010, Global Economic Prospects (Washington: World Bank). 
Table 1. Private Finance: Cross-Country Regressions

\begin{tabular}{|c|c|c|c|c|c|c|c|c|}
\hline & \multicolumn{4}{|c|}{$\begin{array}{c}\text { Net Private Capital Inflows } \\
\text { (percent of GDP, average 2001-07) }\end{array}$} & \multicolumn{4}{|c|}{$\begin{array}{c}\text { Domestic Credit } \\
\text { (Private sector credit / GDP, average 2001-07) }\end{array}$} \\
\hline & $\begin{array}{c}\text { (1) OLS } \\
\text { Indep. Vars: } \\
\text { average 2001-07 }\end{array}$ & $\begin{array}{c}\text { (2) OLS } \\
\text { Indep. Vars: first } \\
\text { available year, } \\
2001-07\end{array}$ & $\begin{array}{c}\text { (3) OLS } \\
\text { Indep. Vars: } \\
\text { average 1998- } \\
2000\end{array}$ & $\begin{array}{c}\text { (4) IV } \\
\text { Instruments: } \\
\text { average 1998- } \\
2000\end{array}$ & $\begin{array}{l}\text { (5) OLS } \\
\text { Indep. Vars: } \\
\text { average } \\
2001-07 \\
\end{array}$ & $\begin{array}{c}\text { (6) OLS } \\
\text { Indep. Vars: } \\
\text { first available } \\
\text { year, 2001-07 }\end{array}$ & $\begin{array}{c}\text { (7) OLS } \\
\text { Indep. Vars: } \\
\text { average } \\
1998-2000\end{array}$ & $\begin{array}{c}\text { (8) IV } \\
\text { Instruments: } \\
\text { average } 1998- \\
2000\end{array}$ \\
\hline $\begin{array}{l}\text { Net Private Capital Inflows (percent of } \\
\text { GDP) }\end{array}$ & & & & & $\begin{array}{l}-0.46 \\
(0.44)\end{array}$ & $\begin{array}{c}0.41 \\
(0.32)\end{array}$ & $\begin{array}{c}0.11 \\
(0.35)\end{array}$ & $\begin{array}{l}-0.56 \\
(0.45)\end{array}$ \\
\hline Cost of Capital (percent) & $\begin{array}{l}-0.10 \\
(0.07)\end{array}$ & $\begin{array}{c}0.16 \\
(0.18)\end{array}$ & $\begin{array}{c}0.18 \\
(0.12)\end{array}$ & $\begin{array}{l}-0.11 \\
(0.08)\end{array}$ & $\begin{array}{c}-0.94 * * \\
(0.45)\end{array}$ & $\begin{array}{c}-1.72 * * \\
(0.81)\end{array}$ & $\begin{array}{c}-1.88^{* *} \\
(0.82)\end{array}$ & $\begin{array}{c}-0.83^{* *} \\
(0.35)\end{array}$ \\
\hline Institutional quality: KKM index & $\begin{array}{l}0.10^{* *} \\
(0.04)\end{array}$ & $\begin{array}{l}0.09^{* *} \\
(0.04)\end{array}$ & $\begin{array}{l}0.10^{* *} \\
(0.04)\end{array}$ & $\begin{array}{c}0.11^{* * *} \\
(0.04)\end{array}$ & $\begin{array}{c}0.75^{* * * *} \\
(0.17)\end{array}$ & $\begin{array}{c}0.57^{* * *} \\
(0.16)\end{array}$ & $\begin{array}{c}0.55^{* * *} \\
(0.14)\end{array}$ & $\begin{array}{c}0.74 * * * \\
(0.19)\end{array}$ \\
\hline $\begin{array}{l}\text { Exports of goods and services (percent of } \\
\text { GDP) }\end{array}$ & $\begin{array}{c}0.10^{* * *} \\
(0.04)\end{array}$ & $\begin{array}{c}0.10^{* * *} \\
(0.04)\end{array}$ & $\begin{array}{c}0.09 * * * \\
(0.03)\end{array}$ & $\begin{array}{c}0.11 * * * \\
(0.04)\end{array}$ & $\begin{array}{l}0.36^{* *} \\
(0.15)\end{array}$ & $\begin{array}{c}0.25 \\
(0.15)\end{array}$ & $\begin{array}{l}0.32 * * \\
(0.14)\end{array}$ & $\begin{array}{l}0.35^{* *} \\
(0.15)\end{array}$ \\
\hline $\begin{array}{l}\text { General government budget balance } \\
\text { (percent of GDP) }\end{array}$ & $\begin{array}{c}0.12 \\
(0.12)\end{array}$ & $\begin{array}{c}0.02 \\
(0.07)\end{array}$ & $\begin{array}{l}-0.12 \\
(0.10)\end{array}$ & $\begin{array}{l}-0.31 \\
(0.22)\end{array}$ & $\begin{array}{c}0.64 \\
(0.58)\end{array}$ & $\begin{array}{c}0.92 * * * \\
(0.26)\end{array}$ & $\begin{array}{c}0.73 * * \\
(0.30)\end{array}$ & $\begin{array}{c}0.59 \\
(0.58)\end{array}$ \\
\hline CPI Inflation $(\log )$ & $\begin{array}{c}0.01 \\
(0.54)\end{array}$ & $\begin{array}{l}-0.42 \\
(0.45)\end{array}$ & $\begin{array}{l}-0.33 \\
(0.38)\end{array}$ & $\begin{array}{l}-0.03 \\
(0.64)\end{array}$ & $\begin{array}{l}-2.98 \\
(2.75)\end{array}$ & $\begin{array}{l}-4.22 * \\
(2.35)\end{array}$ & $\begin{array}{l}-3.70^{*} \\
(1.92)\end{array}$ & $\begin{array}{c}-8.93^{* *} \\
(4.43)\end{array}$ \\
\hline Indicator: Large exporter of fuel & $\begin{array}{l}-1.42 \\
(2.07)\end{array}$ & $\begin{array}{l}-1.86 \\
(1.64)\end{array}$ & $\begin{array}{l}-1.66 \\
(2.05)\end{array}$ & $\begin{array}{c}0.47 \\
(2.31)\end{array}$ & $\begin{array}{c}2.28 \\
(6.73)\end{array}$ & $\begin{array}{l}-0.46 \\
(5.08)\end{array}$ & $\begin{array}{c}5.56 \\
(5.06)\end{array}$ & $\begin{array}{c}3.52 \\
(7.02)\end{array}$ \\
\hline Indicator: Large exporter of metals & $\begin{array}{c}1.11 \\
(1.62)\end{array}$ & $\begin{array}{c}0.98 \\
(1.44)\end{array}$ & $\begin{array}{c}0.66 \\
(1.65)\end{array}$ & $\begin{array}{c}1.15 \\
(1.60)\end{array}$ & $\begin{array}{c}1.39 \\
(7.15)\end{array}$ & $\begin{array}{c}1.89 \\
(5.57)\end{array}$ & $\begin{array}{c}5.98 \\
(6.24)\end{array}$ & $\begin{array}{c}1.33 \\
(6.96)\end{array}$ \\
\hline Constant & $\begin{array}{c}1.57 \\
(2.54)\end{array}$ & $\begin{array}{l}-1.60 \\
(4.27)\end{array}$ & $\begin{array}{l}-2.53 \\
(3.19)\end{array}$ & $\begin{array}{c}0.06 \\
(2.54)\end{array}$ & $\begin{array}{c}11.33 \\
(13.01)\end{array}$ & $\begin{array}{c}41.43 * * \\
(18.75)\end{array}$ & $\begin{array}{c}44.55^{* *} \\
(20.65)\end{array}$ & $\begin{array}{c}20.24 \\
(15.16)\end{array}$ \\
\hline Observations & 103 & 103 & 102 & 103 & 103 & 103 & 102 & 102 \\
\hline $\mathrm{R}^{2}$ & 0.371 & 0.352 & 0.311 & 0.306 & 0.448 & 0.502 & 0.538 & 0.410 \\
\hline
\end{tabular}

Notes: ***, **, and * denote significance at the, respectively, 10 percent, 5 percent, and 1 percent level. Significance is evaluated using robust standard errors (in parentheses). Endogenous regressors are identified using the Durbin-Wu-Hausman test. 
Table 2. Private Finance: Panel Regressions

\begin{tabular}{|c|c|c|c|c|c|c|c|c|c|c|}
\hline Explanatory variables: & $\begin{array}{c}\text { Net Private } \\
\text { Capital Inflows } \\
\text { (pct. of GDP) }\end{array}$ & $\begin{array}{c}\text { Net Equity } \\
\text { Inflows (pet. of } \\
\text { GDP) } \\
\end{array}$ & $\begin{array}{c}\text { Net Debt } \\
\text { Inflows (pet. of } \\
\text { GDP) } \\
\end{array}$ & $\begin{array}{c}\text { Net Bank } \\
\text { Inflows (pet. of } \\
\text { GDP) } \\
\end{array}$ & $\begin{array}{c}\text { Net Bond } \\
\text { Inflows (pet. of } \\
\text { GDP) } \\
\end{array}$ & \multicolumn{5}{|c|}{$\begin{array}{c}\text { Domestic Credit } \\
\text { (private sector credit, pet. of GDP) }\end{array}$} \\
\hline $\begin{array}{l}\text { Net Private Capital Inflows (percent } \\
\text { of GDP) }\end{array}$ & & & & & & $\begin{array}{l}0.26^{* *} \\
(0.11)\end{array}$ & & & & \\
\hline Net Equity Inflows (percent of GDP) & & & & & & & $\begin{array}{l}0.22 * \\
(0.13)\end{array}$ & & & \\
\hline Net Debt Inflows (percent of GDP) & & & & & & & & $\begin{array}{l}0.32 * * \\
(0.15)\end{array}$ & & \\
\hline Net Bank Inflows (percent of GDP) & & & & & & & & & $\begin{array}{l}1.00^{* *} \\
(0.43)\end{array}$ & \\
\hline Net Bond Inflows (percent of GDP) & & & & & & & & & & $\begin{array}{c}0.21 \\
(0.34)\end{array}$ \\
\hline Global price of risk & $\begin{array}{c}-1.79 * * * \\
(0.44)\end{array}$ & $\begin{array}{c}-1.08 * * * \\
(0.29)\end{array}$ & $\begin{array}{l}-0.72 * * \\
(0.33)\end{array}$ & $\begin{array}{l}-0.25 \\
(0.22)\end{array}$ & $\begin{array}{l}-0.16 \\
(0.12)\end{array}$ & $\begin{array}{l}-1.73^{*} \\
(0.89)\end{array}$ & $\begin{array}{l}-1.91 * * \\
(0.90)\end{array}$ & $\begin{array}{c}-1.85^{* *} \\
(0.92)\end{array}$ & $\begin{array}{l}-1.60^{*} \\
(0.91)\end{array}$ & $\begin{array}{c}-2.03 * * \\
(0.93)\end{array}$ \\
\hline Cost of capital (percent) & $\begin{array}{l}-0.06 \\
(0.09)\end{array}$ & $\begin{array}{l}-0.00 \\
(0.04)\end{array}$ & $\begin{array}{l}-0.06 \\
(0.07)\end{array}$ & $\begin{array}{l}-0.06 \\
(0.06)\end{array}$ & $\begin{array}{l}-0.01 \\
(0.05)\end{array}$ & $\begin{array}{l}-0.27 \\
(0.23)\end{array}$ & $\begin{array}{l}-0.28 \\
(0.22)\end{array}$ & $\begin{array}{l}-0.27 \\
(0.24)\end{array}$ & $\begin{array}{l}-0.30 \\
(0.23)\end{array}$ & $\begin{array}{l}-0.28 \\
(0.23)\end{array}$ \\
\hline Institutional quality: KKM index & $\begin{array}{c}0.08 \\
(0.09)\end{array}$ & $\begin{array}{l}0.13^{*} \\
(0.07)\end{array}$ & $\begin{array}{l}-0.05 \\
(0.04)\end{array}$ & $\begin{array}{l}-0.05 \\
(0.05)\end{array}$ & $\begin{array}{c}0.05 \\
(0.04)\end{array}$ & $\begin{array}{c}0.23^{* *} \\
(0.11)\end{array}$ & $\begin{array}{l}0.25^{* *} \\
(0.11)\end{array}$ & $\begin{array}{c}0.25^{* *} \\
(0.11)\end{array}$ & $\begin{array}{l}0.24^{* *} \\
(0.11)\end{array}$ & $\begin{array}{c}0.27 * * \\
(0.11)\end{array}$ \\
\hline $\begin{array}{l}\text { Exports of goods and services } \\
\text { (percent of GDP) }\end{array}$ & $\begin{array}{c}0.02 \\
(0.07)\end{array}$ & $\begin{array}{l}-0.04 \\
(0.06)\end{array}$ & $\begin{array}{c}0.06 \\
(0.04)\end{array}$ & $\begin{array}{c}0.01 \\
(0.02)\end{array}$ & $\begin{array}{l}-0.00 \\
(0.02)\end{array}$ & $\begin{array}{l}-0.06 \\
(0.08)\end{array}$ & $\begin{array}{l}-0.05 \\
(0.08)\end{array}$ & $\begin{array}{l}-0.07 \\
(0.08)\end{array}$ & $\begin{array}{l}-0.06 \\
(0.08)\end{array}$ & $\begin{array}{l}-0.06 \\
(0.08)\end{array}$ \\
\hline $\begin{array}{l}\text { General government budget balance } \\
\text { (percent of GDP) }\end{array}$ & $\begin{array}{l}-0.06 \\
(0.19)\end{array}$ & $\begin{array}{l}-0.03 \\
(0.18)\end{array}$ & $\begin{array}{l}-0.04 \\
(0.04)\end{array}$ & $\begin{array}{c}0.04 \\
(0.04)\end{array}$ & $\begin{array}{l}-0.04 \\
(0.04)\end{array}$ & $\begin{array}{c}0.07 \\
(0.10)\end{array}$ & $\begin{array}{c}0.06 \\
(0.09)\end{array}$ & $\begin{array}{c}0.07 \\
(0.08)\end{array}$ & $\begin{array}{c}0.06 \\
(0.08)\end{array}$ & $\begin{array}{c}0.06 \\
(0.08)\end{array}$ \\
\hline CPI Inflation (log) & $\begin{array}{c}0.38 \\
(0.53)\end{array}$ & $\begin{array}{c}0.62 \\
(0.48)\end{array}$ & $\begin{array}{l}-0.23 \\
(0.30)\end{array}$ & $\begin{array}{c}0.22 \\
(0.15)\end{array}$ & $\begin{array}{l}-0.22 \\
(0.15)\end{array}$ & $\begin{array}{l}-0.46 \\
(0.43)\end{array}$ & $\begin{array}{l}-0.45 \\
(0.43)\end{array}$ & $\begin{array}{l}-0.21 \\
(0.43)\end{array}$ & $\begin{array}{l}-0.33 \\
(0.39)\end{array}$ & $\begin{array}{l}-0.24 \\
(0.43)\end{array}$ \\
\hline Indicator: Large exporter of fuel & $\begin{array}{l}-0.23 \\
(1.40)\end{array}$ & $\begin{array}{c}0.38 \\
(1.22)\end{array}$ & $\begin{array}{l}-0.62 \\
(0.75)\end{array}$ & $\begin{array}{l}-0.14 \\
(0.51)\end{array}$ & $\begin{array}{c}0.03 \\
(0.23)\end{array}$ & $\begin{array}{l}-0.69 \\
(1.88)\end{array}$ & $\begin{array}{l}-1.22 \\
(1.86)\end{array}$ & $\begin{array}{l}-0.52 \\
(1.89)\end{array}$ & $\begin{array}{l}-0.66 \\
(2.02)\end{array}$ & $\begin{array}{l}-1.18 \\
(1.89)\end{array}$ \\
\hline Indicator: Large exporter of metals & $\begin{array}{l}-0.16 \\
(1.15)\end{array}$ & $\begin{array}{c}0.53 \\
(0.86)\end{array}$ & $\begin{array}{l}-0.69 \\
(0.77)\end{array}$ & $\begin{array}{c}0.20 \\
(0.40)\end{array}$ & $\begin{array}{l}-0.16 \\
(0.21)\end{array}$ & $\begin{array}{l}-1.89 \\
(1.65)\end{array}$ & $\begin{array}{l}-1.67 \\
(1.69)\end{array}$ & $\begin{array}{l}-1.76 \\
(1.60)\end{array}$ & $\begin{array}{l}-1.46 \\
(1.78)\end{array}$ & $\begin{array}{l}-1.54 \\
(1.65)\end{array}$ \\
\hline Constant & $\begin{array}{c}2.92 \\
(5.21)\end{array}$ & $\begin{array}{l}-0.10 \\
(4.50)\end{array}$ & $\begin{array}{l}3.03 \\
(2.50)\end{array}$ & $\begin{array}{c}3.06 \\
(1.97)\end{array}$ & $\begin{array}{l}-0.83 \\
(1.53)\end{array}$ & $\begin{array}{c}29.10 * * * \\
(6.13)\end{array}$ & $\begin{array}{c}28.90 * * * \\
(6.20)\end{array}$ & $\begin{array}{c}29.39 * * * \\
(6.16)\end{array}$ & $\begin{array}{c}29.82 * * * \\
(6.23)\end{array}$ & $\begin{array}{c}29.08^{* * *} \\
(6.19)\end{array}$ \\
\hline $\begin{array}{l}\text { Observations } \\
\mathrm{R}^{2}\end{array}$ & $\begin{array}{c}602 \\
0.057\end{array}$ & $\begin{array}{c}602 \\
0.047\end{array}$ & $\begin{array}{c}598 \\
0.044\end{array}$ & $\begin{array}{c}598 \\
0.039\end{array}$ & $\begin{array}{c}598 \\
0.014\end{array}$ & $\begin{array}{c}592 \\
0.174\end{array}$ & $\begin{array}{c}592 \\
0.148\end{array}$ & $\begin{array}{c}587 \\
0.161\end{array}$ & $\begin{array}{c}587 \\
0.200\end{array}$ & $\begin{array}{c}587 \\
0.135\end{array}$ \\
\hline
\end{tabular}

Notes: All regressions are estimated using annual data over $2001-07$, with all independent variables lagged once and controlling for country-specific fixed effects. $* * * * *$, and $*$ denote significance at the, respectively, 10 percent, 5 percent, and 1 percent level. Significance is evaluated using robust standard errors (in parentheses). 
Table 3. Decomposition of Cross-Country Differences in Financial Variables

(percent of GDP)

Difference Between Top and Bottom Quartile of Dependent

Variable (time average)

Contribution of differences in (time average of): ${ }^{10}$

Cost of capital

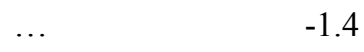

Institutional quality

3.0

Exports of goods and services

Export market growth, 1990-97

$-3.0$

Inflation

$\ldots$

Table 4. Decomposition of Inter-Temporal Changes in Financial Variables

\begin{tabular}{|c|c|c|}
\hline Financial Variables & $\begin{array}{c}\text { Net Private } \\
\text { Capital Inflows }\end{array}$ & Domestic Credit \\
\hline & \multicolumn{2}{|c|}{ (percent of GDP) } \\
\hline $\begin{array}{l}\text { Change Over 2001-07 in Dependen } \\
\text { average) }\end{array}$ & 5.6 & 8.07 \\
\hline \multicolumn{3}{|c|}{ Contribution of changes in (country average of): ${ }^{11}$} \\
\hline Global price of risk & 2.6 & 2.5 \\
\hline Institutional quality & $\ldots$ & -0.10 \\
\hline Net private capital inflows & $\ldots$ & 1.5 \\
\hline
\end{tabular}

${ }^{10}$ Calculated as the product of the cross-sectional regression coefficients (Table 1, preferred specifications in columns 4 and 8) and the time-averaged difference between the top and bottom quartile of the relevant variable. Values shown only where the coefficients are statistically significant.

${ }^{11}$ Calculated as the product of the panel regression coefficients (Table 2) and the country-averaged change over 2001-07 in the relevant variable (for the KKM index, the change is calculated over 2002-07, since values for 2001 are not available). Values shown only where the coefficients are statistically significant. 
Table 5. Investment: Cross-Country Regressions

\begin{tabular}{|c|c|c|c|c|c|c|c|c|}
\hline & \multicolumn{8}{|c|}{ Investment (percent of GDP, average 2001-07) } \\
\hline & \multicolumn{2}{|c|}{$\begin{array}{c}\text { (1) OLS } \\
\text { Indep. Vars: } \\
\text { average 2001-07 }\end{array}$} & \multicolumn{2}{|c|}{$\begin{array}{c}\text { (2) OLS } \\
\text { Indep. Vars: } \\
\text { first available year, } \\
2001-07\end{array}$} & \multicolumn{2}{|c|}{$\begin{array}{c}\text { (3) OLS } \\
\text { Indep. Vars: } \\
\text { average 1998-2000 }\end{array}$} & \multicolumn{2}{|c|}{$\begin{array}{c}\text { (4) IV } \\
\text { Instrument: } \\
\text { private sector credit } \\
1998-2000\end{array}$} \\
\hline \multirow{2}{*}{$\begin{array}{l}\text { Investment (pre-period average } \\
1998-2000, \text { percent of GDP) }\end{array}$} & & $0.68 * * *$ & & $0.62 * * *$ & & $0.65 * * *$ & & $0.69 * * *$ \\
\hline & & $(0.13)$ & & $(0.14)$ & & $(0.14)$ & & $(0.13)$ \\
\hline \multirow[t]{2}{*}{ Cost of capital (percent) } & $-0.40 * * *$ & $-0.30 * *$ & $-0.66^{* * *}$ & $-0.51 * * *$ & -0.02 & 0.02 & $-0.43 * * *$ & $-0.34 * * *$ \\
\hline & $(0.15)$ & $(0.12)$ & $(0.20)$ & $(0.19)$ & $(0.21)$ & $(0.17)$ & $(0.14)$ & $(0.11)$ \\
\hline \multirow[t]{2}{*}{ Institutional quality: KKM index } & -0.09 & -0.09 & $-0.12 * *$ & $-0.12 * *$ & -0.03 & -0.05 & -0.06 & -0.05 \\
\hline & $(0.08)$ & $(0.06)$ & $(0.06)$ & $(0.05)$ & $(0.06)$ & $(0.05)$ & $(0.07)$ & $(0.06)$ \\
\hline \multirow{2}{*}{$\begin{array}{l}\text { Domestic credit (private sector } \\
\text { credit / GDP) }\end{array}$} & $0.10^{* *}$ & $0.08 * * *$ & 0.02 & 0.01 & 0.00 & 0.02 & 0.06 & 0.03 \\
\hline & $(0.04)$ & $(0.03)$ & $(0.03)$ & $(0.03)$ & $(0.05)$ & $(0.05)$ & $(0.04)$ & $(0.03)$ \\
\hline \multirow{2}{*}{$\begin{array}{l}\text { Net private capital inflows (percent } \\
\text { of GDP) }\end{array}$} & $0.76^{* * *}$ & $0.88 * * *$ & $0.34 *$ & $0.41 * *$ & $1.11 * * *$ & $1.12 * * *$ & $0.72 * * *$ & $0.85 * * *$ \\
\hline & $(0.25)$ & $(0.22)$ & $(0.20)$ & $(0.21)$ & $(0.25)$ & $(0.27)$ & $(0.24)$ & $(0.21)$ \\
\hline \multirow{2}{*}{$\begin{array}{l}\text { Terms of trade growth }(* \text { trade } \\
\quad \text { ratio) }\end{array}$} & -0.02 & -0.00 & -0.30 & -0.36 & 0.18 & 0.03 & -0.01 & 0.01 \\
\hline & $(0.09)$ & $(0.08)$ & $(0.27)$ & $(0.26)$ & $(0.25)$ & $(0.22)$ & $(0.09)$ & $(0.07)$ \\
\hline \multirow{2}{*}{$\begin{array}{l}\text { Export market growth }(* \text { export } \\
\quad \text { ratio) }\end{array}$} & 0.19 & 0.26 & 0.03 & 0.02 & $0.02 * * *$ & $0.02 * * *$ & 0.17 & 0.24 \\
\hline & $(0.23)$ & $(0.21)$ & $(0.05)$ & $(0.05)$ & $(0.01)$ & $(0.01)$ & $(0.22)$ & $(0.19)$ \\
\hline \multirow{2}{*}{$\begin{array}{l}\text { Capital inflows * institutional } \\
\text { quality }\end{array}$} & $0.01 *$ & 0.01 & $0.01 * * *$ & $0.01 * * *$ & -0.00 & -0.00 & 0.01 & 0.00 \\
\hline & $(0.01)$ & $(0.00)$ & $(0.00)$ & $(0.00)$ & $(0.01)$ & $(0.01)$ & $(0.00)$ & $(0.00)$ \\
\hline \multirow[t]{2}{*}{ Capital inflows $*$ domestic credit } & $-0.02 * * *$ & $-0.02 * * *$ & $-0.01 * *$ & $-0.01 * *$ & $-0.01 *$ & $-0.02 * * *$ & $-0.01 * * *$ & $-0.01 * * *$ \\
\hline & $(0.00)$ & $(0.00)$ & $(0.00)$ & $(0.00)$ & $(0.01)$ & $(0.01)$ & $(0.00)$ & $(0.00)$ \\
\hline \multirow[t]{2}{*}{ Indicator: Large exporter of fuel } & 1.50 & 1.52 & 1.70 & 1.94 & 1.40 & 1.09 & 1.60 & 1.62 \\
\hline & $(2.07)$ & $(1.64)$ & $(1.84)$ & $(1.58)$ & $(2.37)$ & $(1.79)$ & $(1.96)$ & $(1.55)$ \\
\hline \multirow[t]{2}{*}{ Indicator: Large exporter of metals } & $-3.82 * *$ & $-3.53 * * *$ & -1.53 & -1.32 & -0.50 & -0.14 & $-3.71 * *$ & $-3.40 * * *$ \\
\hline & $(1.66)$ & $(1.32)$ & $(1.81)$ & $(1.48)$ & $(1.73)$ & $(1.52)$ & $(1.55)$ & $(1.27)$ \\
\hline \multirow[t]{2}{*}{ Constant } & $25.85 * * *$ & $9.97 * *$ & $38.34 * * *$ & $22.86^{* * *}$ & $20.02 * * *$ & 7.88 & $26.75^{* * *}$ & $10.55^{* *}$ \\
\hline & $(4.41)$ & $(4.56)$ & $(5.46)$ & $(6.51)$ & $(6.27)$ & $(5.57)$ & $(4.21)$ & $(4.25)$ \\
\hline \multirow{2}{*}{$\begin{array}{l}\text { Observations } \\
\mathrm{R}^{2}\end{array}$} & 87 & 87 & 84 & 84 & 76 & 76 & 87 & 87 \\
\hline & 0.329 & 0.513 & 0.348 & 0.497 & 0.372 & 0.534 & 0.320 & 0.503 \\
\hline
\end{tabular}

Notes: ***,**, and * denote significance at the, respectively, 10 percent, 5 percent, and 1 percent level. Significance is evaluated using robust standard errors (in parentheses). 
Table 6. Investment: Panel Regressions (Fixed Effects, Difference GMM, and System GMM)

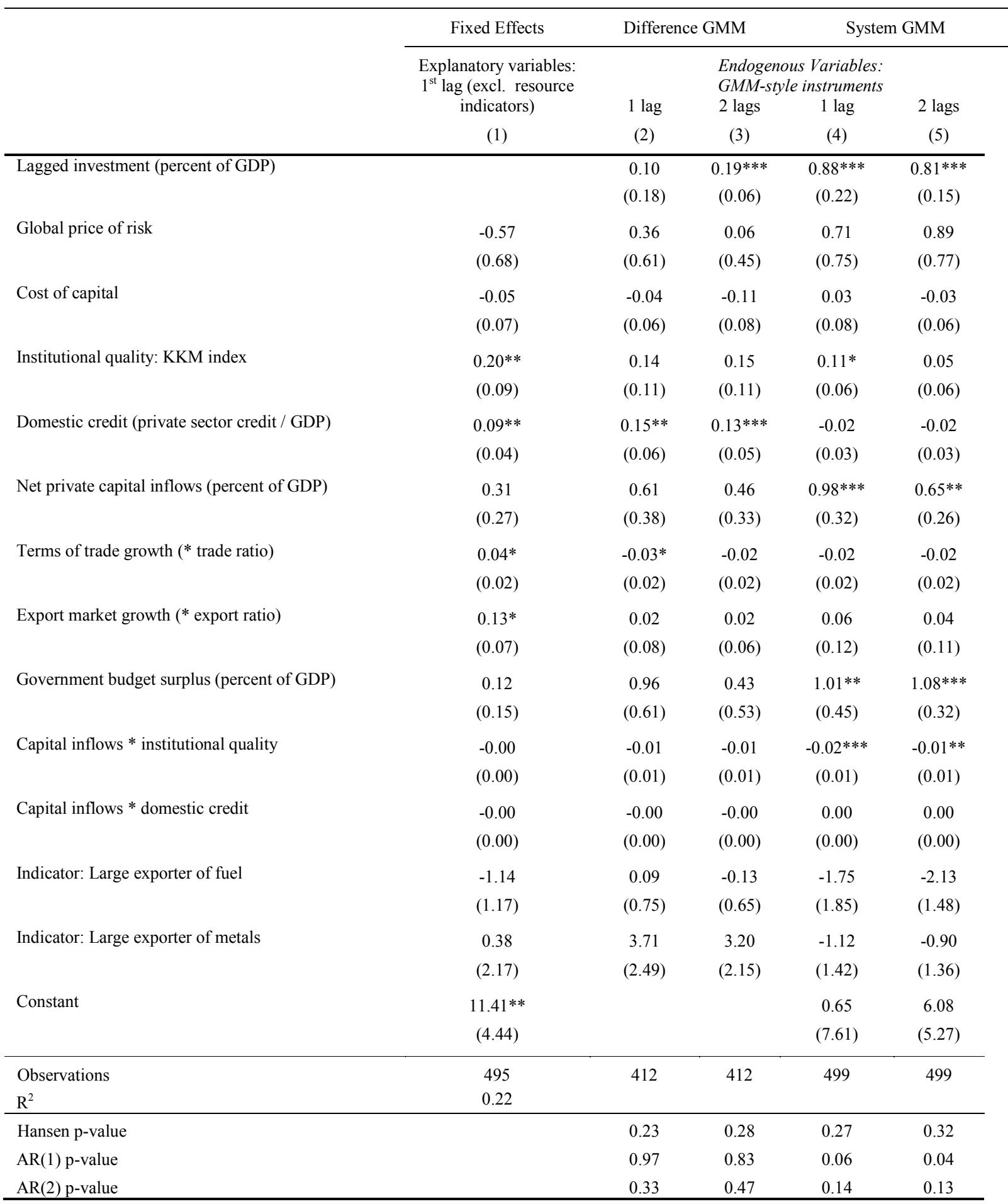

Notes: $* * * * *$, and $*$ denote significance at the, respectively, 10 percent, 5 percent, and 1 percent level. Significance is evaluated using robust standard errors (in parentheses). Specification (1) is estimated using annual data over 2001-07, with all independent variables lagged once, and controlling for country-specific fixed effects. Specifications (2)-(5) are estimated with Investment and Net Capital Inflows as endogenous variables. The GMM-style instruments are the first, or the first and second lags, of the endogenous variables. 
Figure 1. Covariates of Private Finance in Developing Countries.

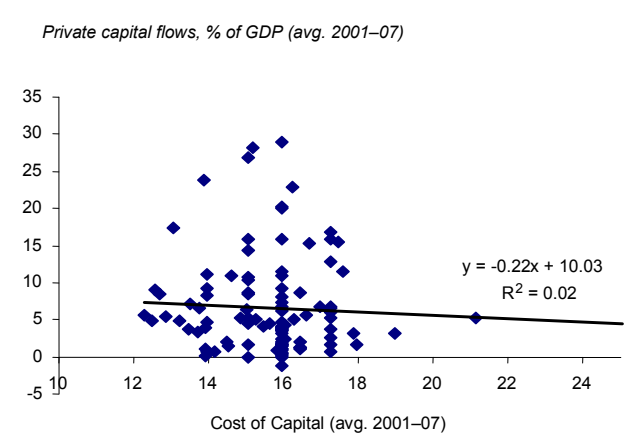

Domestic credit to private sector, \% of GDP (avg. 2001-07)

Private capital flows, \% of GDP (avg. 2001-07)

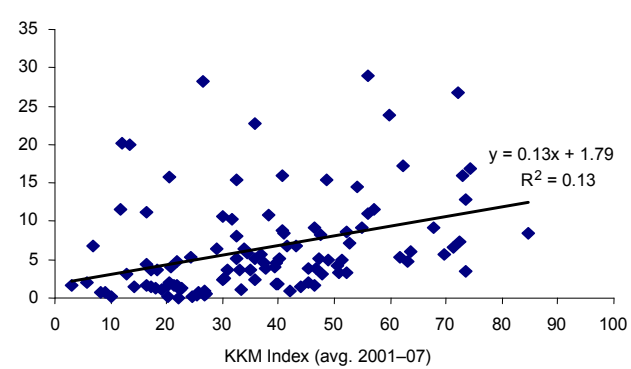

Domestic credit to private sector, \% of GDP (avg. 2001-07)

Private capital flows, \% of GDP (avg. 2001-07)

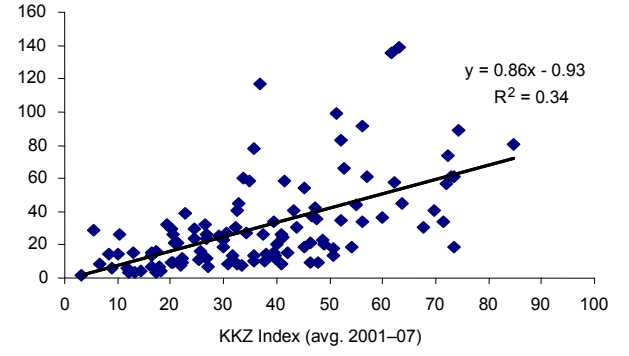

Domestic credit to private sector, \% of GDP (avg. 2001-07)
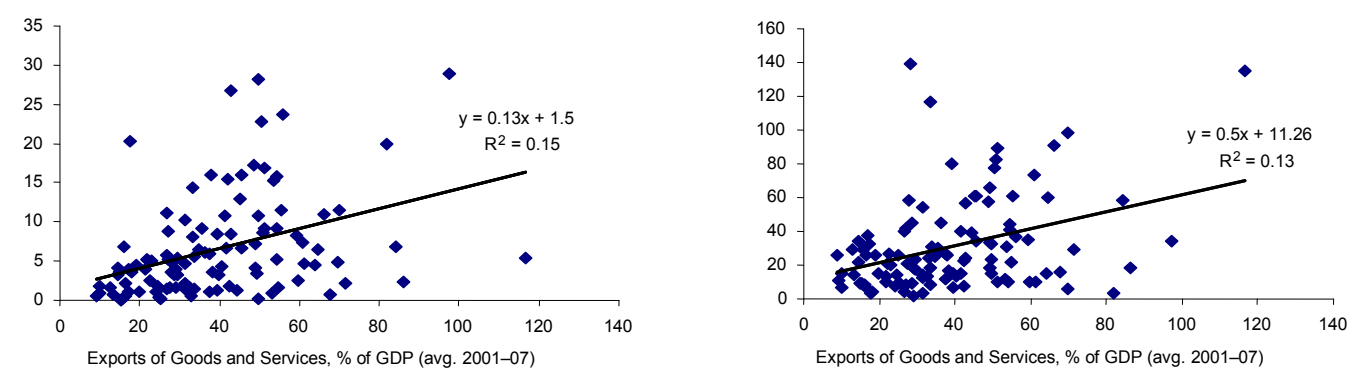

Private capital flows, \% of GDP (avg. 2001-07)

Domestic credit to private sector, \% of GDP (avg. 2001-07)
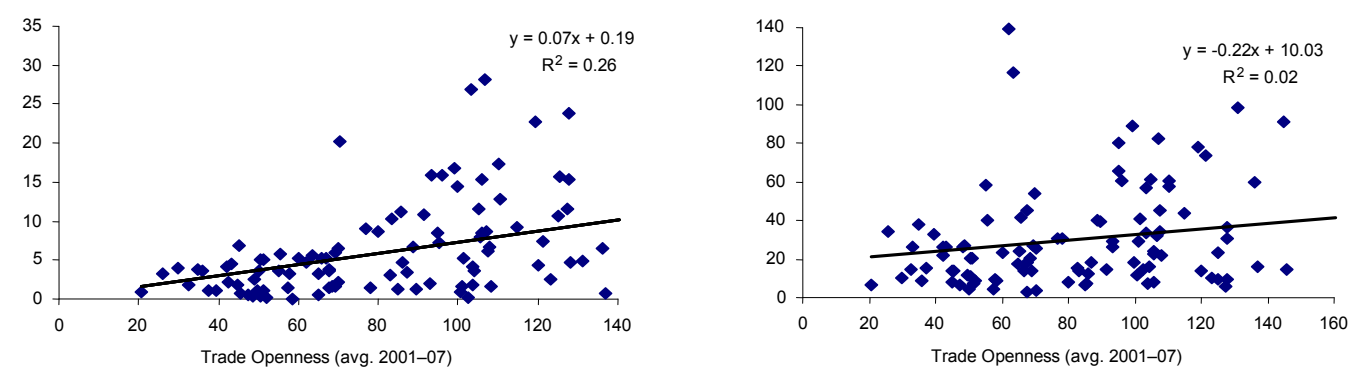

Private capital flows, \% of GDP (avg. 2001-07)

Domestic credit to private sector, \% of GDP (avg. 2001-07)
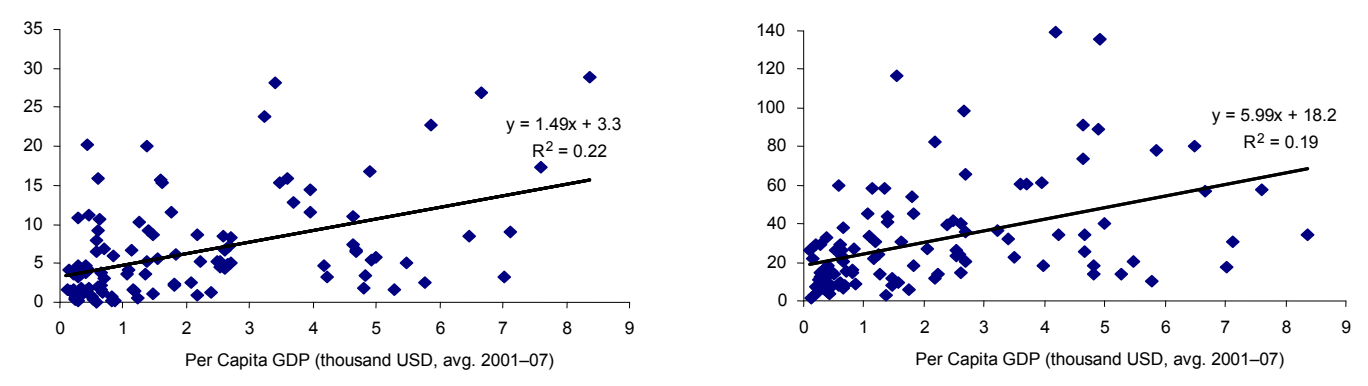

CInternational Monetary Fund. Not for Redistribution 
Appendix Table 1. Country List

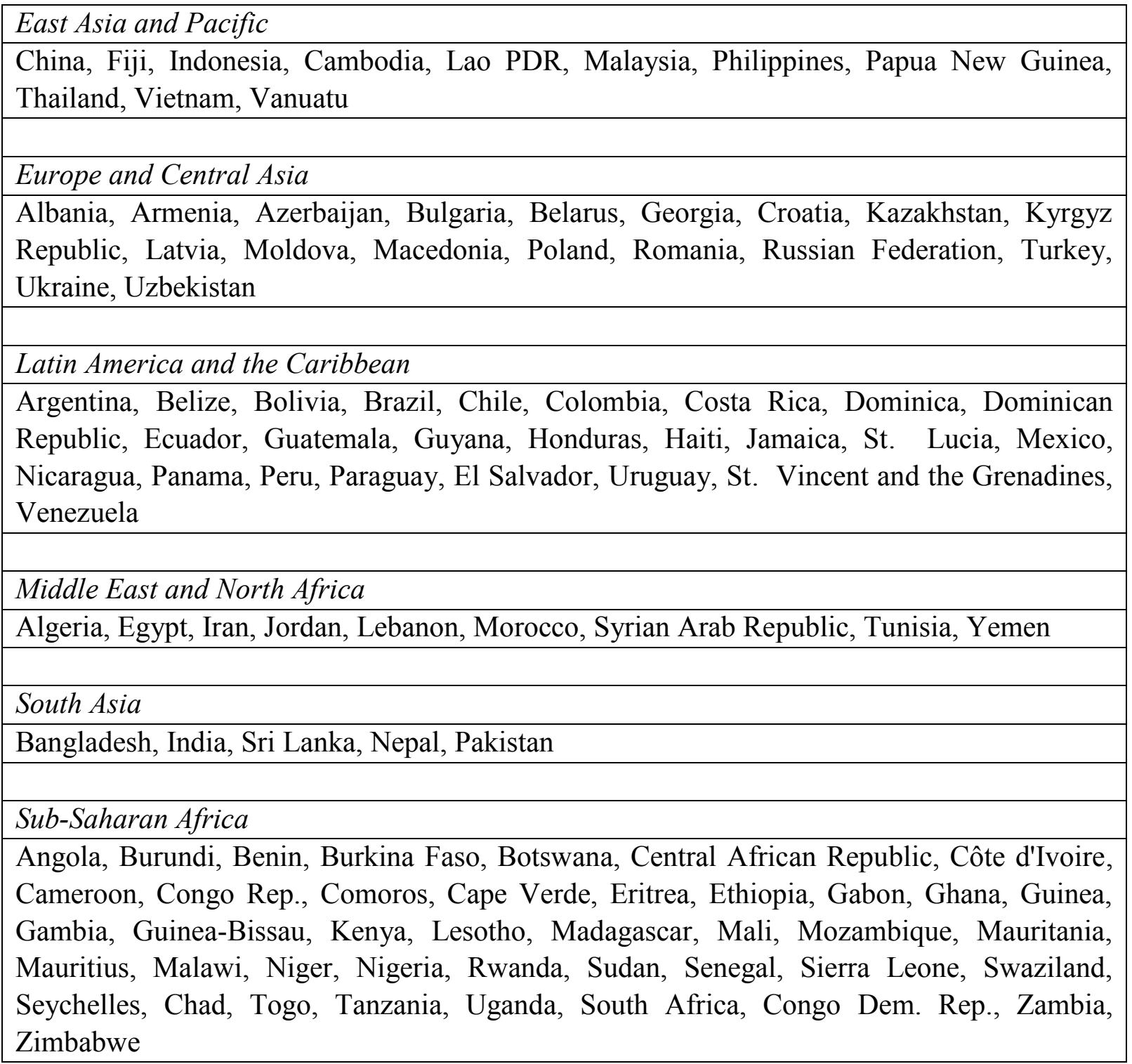


Appendix Table 2. Description of Variables and Data Sources

\begin{tabular}{ll}
\hline Variable & Description \\
\hline Private Capital Inflows & $\begin{array}{l}\text { Private net capital inflows (consisting of debt and equity flows) as a share of nominal } \\
\text { GDP. }\end{array}$ \\
& Source: Global Development Finance, World Bank (2011). \\
& Gross domestic fixed capital as a share of nominal GDP. \\
Investment & Source: World Development Indicators, World Bank (2011). \\
& Domestic credit to the private sector as a share of GDP. \\
Domestic Credit & Source: World Development Indicators, World Bank (2011). \\
& Average across the six governance criteria in the KKM indicators. \\
Institutional Quality: & Source: Governance Matters, World Bank (2009). \\
KKM index & Calculated as the U.S. T-Bill rate, plus the country-specific spread, plus depreciation. \\
Cost of Capital & Source: Datastream and Global Economic Prospects, World Bank (2010). \\
Global Price of Risk & Synthetic risk premium in high-income countries calculated in Kennedy and Palerm \\
& (2009). \\
Export Market Growth & Export market growth, weighted by the trade partner's average share in the country's \\
& total exports (percent). \\
& Source: Global Economic Prospects, World Bank (2010).
\end{tabular}


Appendix Table 3. Descriptive Statistics.

\begin{tabular}{|c|c|c|c|c|c|}
\hline & \\
\hline & Obs. & Mean & Std Dev & Min & Max \\
\hline Net private capital inflows (percent of GDP) & 110 & 6.4 & 6.4 & -1.1 & 28.9 \\
\hline Domestic credit (private sector credit, percent of GDP) & 109 & 30.8 & 27.4 & 1.8 & 139.1 \\
\hline Investment (percent of GDP) & 110 & 22.4 & 7.5 & 6.4 & 44.8 \\
\hline Cost of capital (percent) & 110 & 16.1 & 3.6 & 12.3 & 41.7 \\
\hline Institutional quality: KKM index & 110 & 36.7 & 18.6 & 3.0 & 84.6 \\
\hline Exports of goods and services (percent of GDP) & 110 & 38.9 & 19.8 & 9.0 & 116.7 \\
\hline Government budget surplus (percent of GDP) & 110 & -3.1 & 4.8 & -25.7 & 16.3 \\
\hline CPI Inflation $(\log )$ & 105 & 1.6 & 0.9 & -0.5 & 6.3 \\
\hline Terms of trade growth $(*$ trade ratio, percent) & 107 & 5.1 & 7.2 & -9.7 & 32.9 \\
\hline Export market growth $(*$ export ratio, percent) & 91 & 7.1 & 2.8 & 0.0 & 16.5 \\
\hline Indicator: Resource intensity: mining & 110 & 0.3 & 0.4 & 0.0 & 1.0 \\
\hline Indicator: Resource intensity: petroleum & 110 & 0.2 & 0.4 & 0.0 & 1.0 \\
\hline Interaction: Private capital inflows * institutional quality & 110 & 280 & 353 & -12 & 1,933 \\
\hline \multirow[t]{3}{*}{ Interaction: Private capital inflows $*$ domestic credit } & 109 & 240.6 & 349.2 & -29.3 & 1,773 \\
\hline & \multicolumn{5}{|c|}{ Annual Observations, All Years } \\
\hline & Obs. & Mean & Std Dev & Min & Max \\
\hline Net private capital inflows (percent of GDP) & 769 & 6.4 & 8.9 & -12.7 & 77.1 \\
\hline Domestic credit (private sector credit, percent of GDP) & 750 & 30.8 & 28.3 & 0.7 & 167.3 \\
\hline Investment (percent of GDP) & 770 & 22.4 & 9.0 & 5.3 & 71.0 \\
\hline Cost of capital (percent) & 770 & 16.1 & 4.7 & 11.6 & 69.4 \\
\hline Institutional quality: KKM index & 660 & 36.7 & 18.8 & 2.0 & 86.7 \\
\hline Exports of goods and services (percent of GDP) & 770 & 38.9 & 21.0 & 6.1 & 135.1 \\
\hline Government budget surplus (percent of GDP) & 770 & -3.1 & 6.0 & -36.3 & 28.5 \\
\hline CPI Inflation (log) & 706 & 1.7 & 1.1 & -4.0 & 10.1 \\
\hline Terms of trade growth $(*$ trade ratio, percent) & 721 & 5.1 & 20.3 & -55.7 & 238.6 \\
\hline Export market growth $(*$ export ratio, percent) & 637 & 7.1 & 4.9 & -14.1 & 26.8 \\
\hline Indicator: Resource intensity: mining & 671 & 0.5 & 0.5 & 0.0 & 1.0 \\
\hline Indicator: Resource intensity: petroleum & 671 & 0.3 & 0.5 & 0.0 & 1.0 \\
\hline Interaction: Private capital inflows * institutional quality & 659 & 297 & 481 & -686 & 4,304 \\
\hline Interaction: Private capital inflows * domestic credit & 749 & 252 & 496 & -752 & 4,725 \\
\hline
\end{tabular}

Period Averages, 2001-07 